\title{
EXPENDITURES ON AIR POLLUTION CONTROL UNDER FEDERAL REGULATION
}

\author{
Robert Quinn and Bruce Yandle*
}

\section{Introduction}

In 1983 Yandle (1983) reported results of an empirical examination of the determinants of 1967 state and local regulatory expenses for the control of air pollution, a period that predated the federal control of air pollution by the Environmental Protection Agency. ${ }^{1}$ Drawing on the special interest theory of government and using a multiple regression test, that research found that air pollution regulation expenditures were positively related to state personal income derived from property, and negatively associated with the number of workers in environmentally intensive industries. ${ }^{2}$ The results supported the hypothesis that competing economic agents influence the political provision of air pollution control in ways that preserve environmental and other forms of wealth.

Air pollution and other environmental regulation migrated from state and local jurisdictions to the federal level in the early 1970s. What was formerly competitive regulation became a highly structured and complex system of federal regulation. The new system was characterized by centralized control and national standards to be attained through the implementation of EPA-approved plans. When a state plan was approved, meaning that the plan was in accord with EPA standards, state and local governments became the agents of control. Along with the migration of control to the national level of government came transfers of tax revenue to partially fund the operation of federally approved state pollution control programs. Earlier state flexibility applied in the design and enforcement of standards was arguably transformed into federal control, with variances allowed for standards and enforcement determined partly at the federal level. $^{3}$

The research reported here seeks to explain the level of expenditures incurred by states on

*Instructor, University of Southwestern Louisiana, and Alumni Professor of Economics, Clemson University. regulatory activities for air pollution control during the federal period, as contrasted with the earlier state-control period. The paper first discusses theoretical propositions on special interest influence of federally determined air pollution expenditures. The next section reports statistical tests for 1972, 1976, and 1979 using the earlier Yandle model and an expansion of it based on propositions developed in the previous section. A brief summary concludes the piece.

\section{Background and Theory}

During the pre-EPA period when state and local governments had sole responsibility for devising, enforcing and funding environmental regulations, competition among states for amenities and a healthful environment as well as for economic growth served to bring about regulatory diversity and differing goals for environmental quality. The heterogeniety of income, employment opportunities, environmental scarcity and demographic characteristics of populations across the states predicts efforts to attain different equilibrium levels of air pollution regulation.

Interest groups that sought to influence outcomes in the pre-federal period had to focus their efforts on state and local governments. Those who assigned higher values to cleaner air tried to obtain tighter state regulations. At the same time, some polluters migrated to other locations where populations placed a higher relative value on employment and industrial growth. As a consequence, goods as well as pollution were sometimes shipped back to former locations.

Although specialized factors located in a state might successfully use state regulation to reduce competitive entry into particular industries, the opportunities for such behavior were understandably limited, relative to the federal period. ${ }^{4}$ While plant mobility had to be reckoned with, local property owners were arguably better situated in the pre as opposed to the post-federal period to influence en- 
vironmental outcomes that affected individual patterns of real wealth. Large in number and diverse in interests, local property owners have less difficulty organizing at the local than at the federal level. And local citizens clearly have better information about the relative economic effects of cleaner air and industrial employment on their land values than would a nationally organized coalition. Local citizens can also monitor their local environment and those responsible for regulating it at a lower cost than those at more distant places. ${ }^{6}$

Workers in industrial plants also are arguably better situated to influence city councils and state legislators than representatives and regulators at the federal level regarding the health-employment tradeoffs when enforcement of air quality regulations is being contemplated. While it is true that labor unions are organized and function effectively at the national level, we are not convinced that the effects of labor demands regarding levels of pollution control would be stronger overall at the federal level. We think the effects would be different. That is, highly visible national industries and particular regulatory efforts would garner union support in the federal arena. But the interests of workers in scattered locations might not be as well represented when uniform standards are being devised to replace diverse ones. In any case, the position taken by workers in environmentally intensive industries would represent a balancing of their concerns for their environment and employment ${ }^{6}$.

Yandle's earlier research supported some of these theoretical propositions. His regression model used to predict state and local expenditures for pollution control included the number of workers in five polluting industries, the level of state personal income derived from property and the percent of the labor force unionized. The first two explanatory variables were found to be significantly associated with expenditures, with employment negatively related and property income positive in its association. The union variable was not significantly associated with expenditures, but its sign was negative. The findings seem to indicate that demands for cleaner air are balanced against demands for employment security.

When the locus of regulation moved to the federal government, the dimensions of the special interest struggle changed. Some special interest groups have become viable con- tenders, whereas they could not before. The minimum efficient scale of firm for lobbying at the national level is smaller, we argue, than for the firm that lobbies at both the state and federal levels. Further, there was less net gain to be obtained by environmental and other organizations in the pre-EPA period by lobbying 50 states and several hundred local jurisdictions in the hope of gaining tighter or uniform higher standards. Any resulting shifts in the benefit and cost functions for lobbying will dictate that new interests emerge to operate at the federal level with regulation migrates. Among those who likely lost influence are certain local property owners, some workers in local and regional industrial firms and members of unions that tend to focus on local situations.

We cannot predict which way the balance will tilt when these influences change, whether there will be more regulatory expenditures per state or less. Some nationally organized interest groups will have the same goals as those at the local level, who may have lost their points of influence. The added strength of the national group will more than compensate for voice lost at the local level. The reverse outcome can occur in other areas. National groups may desire programs that completely override activities devised to satisfy local citizens. While we cannot predict a priori just how the scales will tilt, we can predict that variations in influence will be observed when expenditures for regulation across the EPA period are analyzed. The observed changes will then reveal which forces were overriding.

Because of national concerns with the air pollution problem, which partly accounts for the migration of regulation to the federal level, we added three independent variables to those used in the earlier Yandle model. First, since national health was at issue, we added state population, predicting its coefficient would be positively related to regulatory expenditures. Next, we added the percentage of total state land owned by the federal government. We felt national lobby groups and federal regulators would be sensitive to this variable and that it would also partly identify a state's demand for environmental quality. Finally, it has been argued that regional interests are a strong political force in dictating the content of federal regulation. There is strong evidence on the basis of voting patterns that such was the 
case when legislation imposing higher control costs on less developed regions was formulated and passed. ${ }^{7}$ On the basis of the prior analysis of legislative voting patterns, we predict that adjusted pollution control expenditures will be no higher in the industry-intensive snowbelt states than in the sunbelt states. In the absence of strategic behavior, one might predict those expenditures to be higher.

Our discussion of the evolution of federal regulation of air pollution presents three propositions that relate to expenditures at the state level on regulatory activities:

1. Expenditures will be significantly related to employment and property-based income, and the relationship will change as federal regulation is imposed across 1972-1979.

2. The percentage of federal land in a state will be positively related to expenditures, and the relationship will strengthen as federal regulation is tightened to protect national parks and forests.

3. There is no systematic difference between expenditures on air pollution regulation as between sunbelt and snowbelt states, other things being equal. That is, strategic behavior in the development and enforcement of regulation is expected to be observed.

\section{The Statistical Model and Results}

The multiple regression model we used to estimate the levels of expenditures on regulatory activities to control air pollution across states in the federal period is written:

$$
\begin{aligned}
& \text { EXP = F(EMPL, VAL, UNION, FEDLAND, } \\
& \text { POP, FROST). }
\end{aligned}
$$

The dependent variable measures air pollution expenditures on regulation, not capital and operating costs. EMPL is employment in five polluting industries, VAL is total value of real property, UNION is the percentage of a state labor force that is organized, FEDLAND is the percentage of total state land owned by the federal government, POP is total state population, and FROST is a zero-one dummy variable set equal to one for frostbelt states. ${ }^{8}$

Estimates of the regression model were run for the years 1972, 1976 and 1979, using data for each state, with the expectation that the explanatory power of the model would increase as the federal period progressed, due partly to the influence of EPA's tighter standards for national park lands, which came in 1977. We first estimated the closest approximation to the original Yandle model, given data availability, for the three time periods and then added the three additional independent variables discussed earlier. ${ }^{\circ}$

The results of the test are shown in Table 1. As indicated, neither UNION nor EMPL is significantly related to expenditures in the first 1972 model. VAL is significant and

Table 1

Regression Results

\begin{tabular}{|c|c|c|c|c|c|c|}
\hline \multirow[b]{2}{*}{ Variable } & \multicolumn{2}{|c|}{1972} & \multicolumn{2}{|c|}{1976} & \multicolumn{2}{|c|}{1979} \\
\hline & 1 & 2 & 1 & 2 & 1 & 2 \\
\hline Intercept & $\begin{array}{l}208.02 \\
(0.425)\end{array}$ & $\begin{array}{r}-507.79 \\
(1.373)\end{array}$ & $\begin{array}{l}583.56 \\
(0.731)\end{array}$ & $\begin{array}{r}-339.69 \\
(0.622)\end{array}$ & $\begin{array}{l}418.59 \\
(0.395)\end{array}$ & $\begin{array}{r}-724.23 \\
(1.040)\end{array}$ \\
\hline EMPL & $\begin{array}{l}.652 \\
(0.233)\end{array}$ & $\begin{array}{r}-8.359 \\
(3.062)\end{array}$ & $\begin{array}{l}11.720 \\
(2.837)\end{array}$ & $\begin{array}{r}-8.132 \\
(1.887)\end{array}$ & $\begin{array}{l}16.067 \\
(3.077)\end{array}$ & $\begin{array}{r}-10.514 \\
(1.991)\end{array}$ \\
\hline VAL & $\begin{array}{l}.059 \\
(3.846)\end{array}$ & $\begin{array}{r}-.0194 \\
(1.166)\end{array}$ & $\begin{array}{l}33.672 \\
(2.524)\end{array}$ & $\begin{array}{r}-21.212 \\
(1.855)\end{array}$ & $\begin{array}{l}35.602 \\
(2.923)\end{array}$ & $\begin{array}{r}-15.746 \\
(1.590)\end{array}$ \\
\hline UNION & $\begin{array}{l}-16.694 \\
(0.759)\end{array}$ & $\begin{array}{r}.8642 \\
(0.050)\end{array}$ & $\begin{array}{l}-29.08 \\
(0.770)\end{array}$ & $\begin{array}{r}-15.948 \\
(0.620)\end{array}$ & $\begin{array}{l}-27.21 \\
(0.524)\end{array}$ & $\begin{array}{r}-20.031 \\
(0.585)\end{array}$ \\
\hline FEDLAND & & $\begin{array}{r}9.519 \\
(1.481)\end{array}$ & & $\begin{array}{l}21.767 \\
(2.183)\end{array}$ & & $\begin{array}{l}33.222 \\
(3.004)\end{array}$ \\
\hline POP & & $\begin{array}{r}.4867 \\
(6.201)\end{array}$ & & $\begin{array}{r}.7265 \\
(7.119)\end{array}$ & & $\begin{array}{r}.9404 \\
(7.708)\end{array}$ \\
\hline FROST & & $\begin{array}{r}164.5 \\
(0.546)\end{array}$ & & $\begin{array}{r}-127.54 \\
(0.280)\end{array}$ & & $\begin{array}{l}99.441 \\
(0.170)\end{array}$ \\
\hline $\begin{array}{l}R^{2} \\
F\end{array}$ & .36 & .68 & .38 & .74 & .42 & .77 \\
\hline $\mathbf{F}$ & 10.36 & 18.47 & 11.34 & 24.36 & 12.84 & 29.31 \\
\hline
\end{tabular}

Dependent Variable: State Expenditures on Regulation

Absolute values of $\mathrm{T}$ statistics are in parentheses. 
positive. In the second equation, with all five independent variables included to account for local and national effects, the coefficient on EMPL is negative, as it was in Yandle's 1967 estimate. POP is highly significant and positive, as predicted, and none of the other variables is significant. We note that the sign reversal for EMPL occurs when POP is in the equation, which suggests that EMPLY was proxying for population. It is interesting that after adjusting for other effects, expenditures on regulation are not influenced by the proxy for property income, but employment effects are clearly present.

Focusing on the 1976 estimate, EMPL and VAL are positive and significant in the abbreviated model. When the model is expanded to account for national influences, the coefficients of EMPL and VAL are negative and significant. Again, the sign on EMPL reverses when POP is included in the model. POP is highly significant and positive, and FEDLAND has a positive relationship with expenditures, which supports the notion that federal regulators show additional concern for federal land, adjusting for the effects of privately held property. The frostbelt dummy indicates expenditures are no higher in the industrial states than elsewhere in 1976.

The 1979 model, which should capture all the effects of special legislation protecting national parks and forests, shows EMPL and VAL to be highly significant and positive in the abbreviated model. When the model is expanded, the coefficients of EMPL and VAL reverse, as they did in the 1976 model, and the association of POP and FEDLAND with expenditures is still positive but with higher levels of significance. Neither UNION nor FROST is significant.

We interpret the results of these estimates to indicate that supply and demand conditions for regulation did change when air pollution regulation moved to the federal level. Of the interest groups reflected in the pre-EPA analysis, certain property owners may have lost some of their effect on political decision making. Employment in environmentally intensive industries is a sensitive variable throughout the periods analyzed when the complete model is used. We note, however, that the significance of EMPL declined across the three periods in the expanded model. Real property income, as proxied by the value of private land, lost its influence in 1972, a period that seems to indicate clearly that a transition from state to federal regulation was occurring. The influence of property income, which was significant in the 1967 study, returns in 1976 and 1979.

Population and federal land, two sensitive variables at the national level, are of increasing significance in explaining expenditures across the time periods, with both variables being rather powerful throughout the analysis. With the advent of transfer payments for partially funding the cost of state pollution programs, these variables become all the more important. Going on, the political struggle between the snowbelt and sunbelt regions appears to continue across the years analyzed. That is, there is no significant difference in adjusted regulatory expenditures between the regions, whereas one might argue that the older industrialized region would have higher expenditures. Of course, it is possible that the full effects of industrialization are accounted for by the other variables in the model. If that is the case, regulatory expenditures are lower where pollution is highest, as proxied by the employment variable. This interpretation suggests the older region has lower regulatory costs, which also supports the contention that regulation was biased against the sunbelt region.

The results of the expanded models also imply that federal land is an important determinant of regulatory effort. As the share of federal land increases, holding constant population, employment and the other independent variables, regulatory expenditures rise. Conversely, the model indicates that as adjusted real property value rises, expenditures for the regulation of air pollution fall. The results suggest the regulators are more sensitive to the protection of publicly held land than to privately held land. In a sense, this result was predicted in our discussion of the enhanced position of environmental lobby groups in the federal period. Once again, these results indicate that union efforts are not an independent force in determining expenditures on environmental regulation.

\section{Final Thoughts}

This article reports research findings that relate to the political economy of air pollution 
regulation. Earlier work examined a period of regulatory federalism when the population of each state determined the extent to which air pollution would be regulated. That work indicated that economic forces within states significantly affected the level of expenditures on regulation. The effects appeared to represent a balance between demand for improvements in air quality and concern for employ. ment and related income.

Our interest in this research was triggered by recognition that the forces of political economy change when the federal government assumes control of previously state-regulated activities. The results of our empirical investigation support the notion that those forces did indeed change, that some things that were important determinants of regulatory expenditures apparently became less important. Other driving forces survived the trip to the nation's capital, and presumably new determining forces entered the arena and significantly affected outcomes.

At present, the EPA is proposing a more significant role for states in the control of pollution. If the regulatory process cycles back to the states, we would expect to see another shuffling of forces that explain regulatory activities.

\section{FOOTNOTES}

'We note that Yandle used a unique data set for control expenditures. The research reported here draws on data that was maintained after the formation of the U.S. Environmental Protection Agency.

'Principal literature that describes the special interest theories of government include: Buchanan, Tollison and Tullock (1980), Peltzman (1976), and Stigler (1971).

'For a discussion of the EPA system and the results obtained since, see Crandall (1983), The Conservation Foundation (1984), Lave and Omenn (1981) and U.S. General Accounting Office (1978). While progress in the reduction of air pollution is documented in these various reports, overall accomplishments under federal regulation are questioned seriously. Crandall's work suggests the rate of improvement in air quality was reduced for several major pollutants when regulation moved to the federal level. Crandall's model holds constant other effects such as lovels of industrial production and energy use, two activities that affect levels of pollution. In other words, if all else is equal, his statistical evidence lends little if any support to the hypothesis that EPA affected any change in environmental quality. Documentation of EPA's record versus public pronouncements by the agency provided in the G.A.O. report add some evidence in support of Crandall's empirical work.

-The problem here, of course, relates to the potential for monopolizing markets by restricting entry through regulation. It is difficult to imagine many situations where sufficient specialized factors are concentrated in one state to accomplish this feat. Federal regulation offers the possibility for industries that are national in scope. On this last point, see Maloney and McCormick (1982), where evidence of monopolization is presented.

'See Yandle (1984), in which congressional voting patterns are analyzed for legislation, setting the locus for control of sulfur dioxide limitations. The empirical evidence indicates state industrial growth is the strong variable explaining the voting patterns. States experiencing growth favored a more flexible system of control. With respect to protection of local amenity values, we recognize that successful efforts by national environmental organizations, possibly in conjunction with industrial groups ceeking uniform standards, could generate external benefits to local property owners, thereby reducing the costs of local agents who might otherwise seek additional environmental quality at their own expense.

-Discussions of positions taken by unions on environmental control, theories regarding those positions, and empirical evidence linking state efforts to control pollution to union membership are found in United Mine Workers (undated), Miller (1984) and Yandle (1985).

'See Pashigian (1982). Also, see Crandall (1983).

- Data for variables were obtained from various issues of the Statistical Abstract of the United States; Department of Labor, Employment and Earnings, States and Arees, 1936-1976, and 1977-1979; Bureau of the Census, Environmental Quality Control Government Finances, and Employment, 1971-1972, 1972-1973, 1975-1976, and 1978-1979. Since income from property was not available for the periods analyzed, we first estimated a relationship between property income for 1969 (the most recent year available) and assessed property values for that year. The model explained 87 percent of the variation in the data. We consequently used assessed property value as the proxy for income from property. The five industries for which employment data were gathered are: stone-clay. glass, primary metals, paper and allied products, chemical and allied products, and petroleum and coal products.

"In a separate work, we added two of the "national" market variables noted above, POP and FEDLAND, for 1967 and reestimated the original Yandle model. Neither POP nor FEDLAND was significant, and the original independent variables maintained their signs and levels of significance. We did not include FROST, since the differential standards were not in effect until after regulation moved to the federal level. We interpret these results to indicate that the demand and supply for pollution regula. tion changed significantly when national influence entered in the federal period. The estimate for the 1972 equation reported in the text supports the same conclusion.

\section{REFERENCES}

Buchanan, James M., Robert D. Tollison and Gordon Tullock. Toward a Theory of the Rent-Seeking Society. College Station: Texas A\&M Press, 1980.

Crandall, Robert W. Controlling Industrial Pollution. The Economics and Politics of Clean Air. Washington: The Brookings Institution, 1983.

Lave, Lester B. and Gilbert S. Omenn. Clearing the Air: Reforming the Clean Air Act. Washington: The Brookings Institution, 1981.

Maloney, Michael T. and Robert E. McCormick. "A Poajtive Theory of Environmental Quality Regulation." Joumal of Lew and Economics. 25 (1982). 99-123.

Miller, James C. III. "Is Organized Labor Rational in Supporting OSHA?" Southern Economic Joumal 50 (1984). 881-885.

Pashigian, Peter B. "Environmental Regulation: Whose Self Interests are Being Protected?" Center for the Study of the Economy and the State, University of Chicago. (1982). 
Peltzman, Sam. "Toward a More General Theory of Regulation." Journal of Law and Economics. 19 (1976) 211-240.

Stiger, George. "The Theory of Economic Regulation." Bell Journal of Economics and Management Science. 2 (1971) 3-21.

The Conservation Foundation. State of the Environment: An Assessment at Mid-Decade. Washington: The Conservation Foundation, 1984.

United Mine Workers of America. "Employment Impacts of Acid Rain," Washington: United Mine Workers of
America. (Undated).

U.S. General Accounting Office. Improvements Needed in Controlling Major Air Pollution Sources. Washington: General Accounting Office, 1978.

Yandle, Bruce. "Economic Agents and the Level of Pollution Control." Public Choice. 40 (1983) 105-109.

"Sulfur Dioxide: State Versus Federal Control." The Joumal of Energy and Development. 25 (1984) 63-72.

"Unions and Environmental Regulation." Journal of Labor Research. 6 (1985) 429-436. 